\title{
Evaluation of soil erosion and ecological rehabilitation in Loess Plateau region in Northwest China using plutonium isotopes
}

\author{
Zhang, Weichao; Xing, Shan; Hou, Xiaolin
}

Published in:

Soil \& Tillage Research

Link to article, DOI:

10.1016/j.still.2019.04.004

Publication date:

2019

Document Version

Peer reviewed version

Link back to DTU Orbit

Citation $(A P A)$ :

Zhang, W., Xing, S., \& Hou, X. (2019). Evaluation of soil erosion and ecological rehabilitation in Loess Plateau region in Northwest China using plutonium isotopes. Soil \& Tillage Research, 191, 162-170.

https://doi.org/10.1016/..still.2019.04.004

\section{General rights}

Copyright and moral rights for the publications made accessible in the public portal are retained by the authors and/or other copyright owners and it is a condition of accessing publications that users recognise and abide by the legal requirements associated with these rights.

- Users may download and print one copy of any publication from the public portal for the purpose of private study or research.

- You may not further distribute the material or use it for any profit-making activity or commercial gain

- You may freely distribute the URL identifying the publication in the public portal 
$1 \quad$ Evaluation of soil erosion and ecological rehabilitation in Loess

a) State Key Laboratory of Loess and Quaternary Geology, Shaanxi Key Laboratory of

b) China Institute for Radiation Protection, Taiyuan, 030006, China

c) Technical University of Denmark, Center for Nuclear Technologies, Risø Campus,

d) CAS Center for Excellence in Quaternary Science and Global Change, Xi'an, 710061, China

e) University of Chinese Academy of Sciences, Beijing, 100049, China

f) Open Studio for Oceanic-Continental Climate and Environment Changes, Pilot National Laboratory for Marine Science and Technology (Qingdao), Qingdao

18 Abstract: Soil erosion is a critical threat to the agriculture and ecosystem in the Chinese

19 Loess Plateau area. Ecological rehabilitation has been applied in large area for reduction

20 of the soil erosion. Six soil depth profiles were collected from Nanxiaohegou watershed

\footnotetext{
* Corresponding author: E-mail address: xiho@dtu.dk (Xiaolin Hou). \# S. Xing and W.C. Zhang have same contribution to this paper.
} 
21 in the Loess Plateau in northwest China and analyzed for the activity concentrations of

22 plutonium isotopes. The measured ${ }^{240} \mathrm{Pu} /{ }^{239} \mathrm{Pu}$ atomic ratios in all these samples

$23(0.186 \pm 0.017)$ showed that the global fallout was the dominant source of plutonium in

24 this region. An exponential decline of ${ }^{239,240} \mathrm{Pu}$ activity concentrations with depth was

25 observed in most of soil profiles. The total inventory of ${ }^{239,240} \mathrm{Pu}$ in the reference site

26 was calculated to be $110 \mathrm{~Bq} / \mathrm{m}^{2}$, agreeing well with the reported total fallout value in

27 this latitude. The soil erosion rates were estimated by comparison with the reference

28 site to be $538-941 \mathrm{t} / \mathrm{km}^{2} / \mathrm{yr}$ in the most of sites. While an excessive inventory of ${ }^{239,240} \mathrm{Pu}$

$29\left(186 \mathrm{~Bq} / \mathrm{m}^{2}\right)$ compared to the reference site was observed in one site in the base area,

30 indicating a significant accumulation of soil occurred in this area. The soil erosion

31 depths were estimated to be 2.4-4.6 cm in most of sites during 1963-2016, which can

32 be classified as minor erosion. Compared with the erosion rates in the Nanxiaohegou

33 watershed in 1963-2012 which was estimated by other methods, it is suggested that the

34 natural grass is better for long-term ecological restoration, especially in slope area.

35 Keyword: ${ }^{239,240} \mathrm{Pu}$; soil erosion; ecological rehabilitation; ICP-MS/MS; Loess Plateau

\section{Introduction}

Soil erosion is one of the severe ecological and environmental challenges

39 worldwide, seriously effecting soil fertility, crop production, water quality ecological system and human survival. More than $60 \%$ of Loess Plateau of China with an area of

$41640,000 \mathrm{~km}^{2}$ suffers the most severe soil erosion in the world, with soil erosion rates 
ranging from $5000 \mathrm{t} / \mathrm{km}^{2} / \mathrm{yr}$ to $10000 \mathrm{t} / \mathrm{km}^{2} / \mathrm{yr}$ (Cai, 2001; Zhao et al., 2013). In order to reduce soil erosion and achieve sustainable development in the Loess Plateau region, large areas of sloping farmland have been prohibited for cultivation and returned to forest or grassland in northwest China since the 1990s (Chen et al., 2015). It is necessary to evaluate the adaptability and effectiveness of the rehabilitation methods. The normalized difference vegetation index and soil erosion rate are two indexes often used to evaluate the effectiveness of ecological rehabilitation (Fu et al., 2017). The normalized difference vegetation index is usually obtained by remote sensor monitoring (Larsson, 1993), it mainly presents a short term or current time effectiveness. The erosion rate of soil can provide information regarding long-term impact, so more accurate and effective in the evaluation of the ecological rehabilitation.

Different techniques have been applied for evaluation of the soil erosion rate, such as runoff plots, field survey, positioning method, remote sensing and radionuclides tracer techniques (Fu et al., 2003; Liu et al., 2018; Su et al., 2018; Sepuru and Dube, 2018; Walling et al., 1999; Xu et al., 2015; Zheng et al., 2007). The runoff plots method (Fu et al., 2003) is used to measure the soil erosion rate of a single event. The field survey (Liu et al., 2018) is rough and not reflect the soil erosion in the short term. Although positioning method (Su et al., 2018) can provide the soil erosion rate in small watersheds, it is difficult to evaluate the soil erosion rate in large watersheds. Remote sensing can be used to evaluate soil erosion in large watershed by estimating the land coverage by vegetation, but the derived results are the short-term data and do not 

technique is a quantitative method for evaluation of soil erosion in both the short- and long- term. This method has been also successfully used to investigate the temporal and spatial variation of soil erosion (Walling et al., 1999; Xu et al., 2015; Zheng et al., 2007). of soil erosion (Walling et al., 1999; Xu et al., 2015; Zheng et al., 2007). Because of the extremely short half-life of ${ }^{7} \mathrm{Be}$ (53.3 days), it can be only used to investigate soil erosion in a short-term of less one year. ${ }^{210} \mathrm{~Pb}$, a daughter radionuclide of ${ }^{222} \mathrm{Rn}$, besides

71 being constantly deposited on the soil from the atmosphere, can be also intrinsically

72 formed from the ${ }^{226} \mathrm{Ra}\left({ }^{238} \mathrm{U}\right)$ in the soil. In addition, the ${ }^{222} \mathrm{Rn}$ can also escape/migrate 73 from the deep soil, making it more complicated for soil erosion investigation (Branford 74 et al., 2004). Also, the low energy gamma emission of ${ }^{210} \mathrm{~Pb}(46.5 \mathrm{keV})$ with low 75 intensity (4.2\%) make its sensitive measurement difficult (Branford et al., 2004). 76 Therefore, ${ }^{210} \mathrm{~Pb}$ is not commonly used for this purpose. Anthropogenic ${ }^{137} \mathrm{Cs}$ originated 77 from the global fallout of nuclear weapons tests mainly in 1961-1962 has been widely 78 used for investigation of soil erosion in the past decades due to its easy measurement 79 using gamma spectrometry. However, the relatively short half-life (30.2 years) makes 80 the level of the global fallout ${ }^{137} \mathrm{Cs}$ in the soil reduced to about a quarter of initiated 81 value by radioactive decay. The accurate measurement of ${ }^{137} \mathrm{Cs}$ in the soil becomes 82 more difficult, especially for the deep soil $(>15 \mathrm{~cm})$, where the ${ }^{137} \mathrm{Cs}$ concentration 83 became too low to be measured by gamma spectrometry. ${ }^{239} \mathrm{Pu}$ and ${ }^{240} \mathrm{Pu}$ are long-lived 

the global fallout of the nuclear weapons tests in the environment. It was reported that plutonium is also highly associated with soil grains when entered into the soil (Zhang

87 et al., 2010), therefore they were suggested as ideal substitutes of ${ }^{137}$ Cs for investigation of soil erosion (Xu et al., 2015; Zheng et al., 2008). In addition, with the rapid development of mass spectrometry, ${ }^{239} \mathrm{Pu}$ and ${ }^{240} \mathrm{Pu}$ can be easily and sensitively measured using inductively coupled plasma mass spectrometry (ICP-MS) in large number of samples (Xing et al., 2018), making it an attractive radionuclide tracer for investigation of soil erosion.

This work aims to assess soil erosion in two catchments with natural vegetation

94 rehabilitation and artificial afforestation rehabilitation in the same region in

95 Nanxiaohegou watershed in the Loess Plateau of northwest China using ${ }^{239} \mathrm{Pu}$ and ${ }^{240} \mathrm{Pu}$

96 as tracers. This is implemented by determination of activity concentration of ${ }^{239} \mathrm{Pu}$ and $97{ }^{240} \mathrm{Pu}$ in 6 soil depth profiles collected in this watershed using extraction 98 chromatography separation of plutonium and ICP-MS/MS measurement of ${ }^{239} \mathrm{Pu}$ and $99{ }^{240} \mathrm{Pu}$. The results are used to evaluate the effectiveness of different ecological 100 rehabilitation methods for reducing soil erosion. 


\section{Materials and Methods}

103

\subsection{Study area and soil sampling}

104

Two ecological rehabilitation areas (Dongzhuanggou (DZG) and Yangjiagou (YJG)

105

catchments) in the Nanxiaohegou watershed $\left(35.7^{\circ} \mathrm{N}, 107.5^{\circ} \mathrm{E}\right)$, located in Loess

106 Plateau in Qingyang, Gansu Province in northwest China (Fig. 1), were selected for

107 investigation of the soil erosion and evaluation of the effectiveness of the different

108 ecological rehabilitation methods in past decades. Nanxiaohegou watershed is a small

109 watershed of $36.5 \mathrm{~km}^{2}$, located at Xifeng Soil and Water Conservation station managed

110 Huanghe Hydrological Committee, the annual average temperature is $9.3^{\circ} \mathrm{C}$ and annual

111 average precipitation rate is $556 \mathrm{~mm}$ in this watershed (Chen, 2010; Jin et al., 2018).

112 DZG and YJG are two adjacent catchments in Nanxiaohegou watershed with a

113 typical hilly-gullied topography of Chinese Loess Plateau. The two catchments are now

114 covered by forest and grass respectively, but were cultivated and planted with crops

115 before 1954. The soil erosion in the Loess Plateau of Northwest China is serious due to

116 soil property of lose and fine grains, extreme precipitation events and extensive land

117 cultivation in this region. The Nanxiaohegou watershed has been used for evaluation of

118 the different methods for rehabilitation since 1954 . In the catchment of DZG $\left(1.15 \mathrm{~km}^{2}\right.$,

$1191.6 \times 0.72 \mathrm{~km}$ ), natural vegetation (grass) restoration without human disturbance was

120 applied for ecological rehabilitation of land since 1954. Agropyron cristatum,

121 Bothriochloa ischaemum, Arundinella hirta, Artemisia argyi and Echinochloa crusgalli

122 are the dominant species of grass in this area. While, an artificial restoration was 
123 adopted in the YJG catchment $\left(0.87 \mathrm{~km}^{2}, 1.5 \times 0.58 \mathrm{~km}\right)$ by planting trees in $1954-1958$,

124 followed by prohibition for any cultivation until present. Robinia pseudoacacia,

125 Armeniaca sibirica, Pinus tabulaeformis, Salix matsudana and Platycladus orientalis

126 are the dominant species of shrubs in this artificial forest. The vegetation coverages of

127 DZG and YJG are 65-90\% (Chen, 2010; Jin et al., 2018). The well documented

128 information and different rehabilitation methods in these two catchments in the

129 Nanxiaohegou watershed as a soil and water conservation observation station provide

130 an idea place for this study in Loess Plateau in Northwest China.

131 Three sites in each catchment of DZG and YJG (Fig. 1) were selected for sampling,

132 i.e. top area (D1/Y1), slope area (D2/Y2) and base area of (D3/Y3). Soil profiles of 40-

$13380 \mathrm{~cm}$ in depth were sampled manually, $2.0 \mathrm{~cm}$ intervals for the top $30 \mathrm{~cm}$ soil and 5.0

$134 \mathrm{~cm}$ intervals for the deeper part $(>30 \mathrm{~cm})$ were taken in Nov. 2016 using a small

135 stainless steel spade. The collected samples were sealed in plastic bags and transported

136 to the laboratory for analysis. The soil was first weighed and air dried. After removal

137 of the stones $(>2 \mathrm{~mm})$ and roots of vegetation, the sample was dried in an oven at $150^{\circ} \mathrm{C}$

138 for 2-3 days until constant weight. The dried samples were ground and sieved through

139 an 80-mesh sieve.

$141 \quad 2.2$ Sample analysis

142 The soil samples were analyzed for plutonium isotopes using radiochemical

143 separation followed by ICP-MS measurement, the detailed analytical method has been 
145 presented here: (1) the dried and ground soil samples were first ashed at $450^{\circ} \mathrm{C}$ 146 overnight and then leached using aqua regia after spiking a known amount of ${ }^{242} \mathrm{Pu}$; (2)

147 the plutonium isotopes were separated from matrix in the leachate by co-precipitation 148 with iron hydroxides, washing with $\mathrm{NaOH}$, (3) the plutonium isotopes were purified 149 using extraction chromatography with TEVA column after adjust plutonium to $\mathrm{Pu}(\mathrm{IV})$; 150 (4) the final separated plutonium sample solution was measured by ICP-MS/MS 151 (Agilent 8800) using $\mathrm{NH}_{3}-\mathrm{He}$ as the reaction gas. With this method, the 152 decontamination factor of uranium in the separated plutonium solution is more than $1535 \times 10^{4}$, the contribution of uranium at $\mathrm{m} / \mathrm{z}=239$ by tailing of ${ }^{238} \mathrm{U}^{+}$and ${ }^{238} \mathrm{U}^{1} \mathrm{H}^{+}$in the 154 ICP-MS/MS was measured to be less than $2 \times 10^{-6}$, the interference of uranium in soil 155 samples for the determination of low level ${ }^{239} \mathrm{Pu}$ and ${ }^{240} \mathrm{Pu}$ was therefore sufficiently 156 removed.

157 The measurement sensitivity for ${ }^{239} \mathrm{Pu}$ and ${ }^{240} \mathrm{Pu}$ is $710 \mathrm{cps} / \mathrm{ppt}$ and chemical recovery 158 of plutonium is $75-95 \%$, and the estimated detection limits of this method for ${ }^{239} \mathrm{Pu}$ and $159{ }^{240} \mathrm{Pu}$ are $0.55 \mathrm{fg} / \mathrm{mL}$ for ${ }^{239} \mathrm{Pu}$ and $0.09 \mathrm{fg} / \mathrm{mL}$ for ${ }^{240} \mathrm{Pu}$ using the procedure blank. The 160 blank was subtracted from the measured results of samples for calculation of the activity

161 concentrations of plutonium isotopes.2.3 Estimation of the soil erosion rate

162 The estimation of the soil erosion using ${ }^{239,240} \mathrm{Pu}$ is based on that ${ }^{239} \mathrm{Pu}$ and ${ }^{240} \mathrm{Pu}$ in 163 the environment is mainly originated from the global fallout of atmospheric nuclear 164 weapons tests and homogenously deposited in the land of certain area (e.g. band of 
165 similar latitude), and highly associated with soil particles (UNSCEAR, 2000). The

166 inventory of ${ }^{239,240} \mathrm{Pu}$ (reserved) in the soil column will be changed when water or wind

167 erosion or accumulation happened, therefore, the variation of the inventory of

168 plutonium in the soil core directly reflects the loss or accumulation of soil (Xu et al.,

169 2015). By comparing the inventory of ${ }^{239,240} \mathrm{Pu}$ measured in the sampling sites with the

170 measured value in the reference site (no significant loss or accumulation of soil), the

171 erosion or accumulation rate of soil can be estimated. Some models have been proposed

172 for estimate the soil erosion rate and depth using radionuclide tracers, a simple and

173 often used mode for estimation of erosion rate of uncultivated soil using radionuclide

174 (e.g. ${ }^{239,240} \mathrm{Pu}$ ) as a tracer was used in this work (Zhang et al. 1999; Walling et al. 2002;

175 Hoo et al., 2011; Lal et al., 2013; Xu et al., 2015)). This model is based on the

176 following four assumptions:

177 (1) The soil erosion rate in the investigated site is constant during in the study

178 period.

179 (2) The decay of radionuclide is neglected or can be corrected during the study

180 period. Due to the very long half-lives of ${ }^{239} \mathrm{Pu}\left(2.41 \times 10^{4}\right.$ years $)$ and ${ }^{240} \mathrm{Pu}\left(6.56 \times 10^{3}\right.$

181 years $)$ compared to the study time span $(<100$ year $)$, there is no need for decay

182 correction.

183 (3) The reference site is defined as the site/area where did not disturbed by human

184 activities and no soil erosion or accumulation occurred. 

tracer. (1) (Hoo et al., 2011).

$$
\mathrm{I}=\int_{0}^{Z} \mathrm{~B} f(z) \mathrm{dz}
$$

191 where $\mathrm{Z}$ is soil depth (m), B is soil bulk density $\left(\times 10^{-3} \mathrm{t} / \mathrm{m}^{3}\right), f(z)$ is the inventory of ${ }^{239,}{ }^{240} \mathrm{Pu}$ in a soil interval $\mathrm{Z}(\mathrm{m})$.

194 site $\left(\mathrm{I}_{\mathrm{st}}\right)$ and reference site $\left(\mathrm{I}_{\mathrm{ref}}\right)$, the loss of ${ }^{239,240} \mathrm{Pu}$ inventory $\left(\mathrm{I}_{\text {loss }}\right)$ due to the soil erosion could be calculated from equation (2) (Hoo et al., 2011; Lal et al., 2013).

$$
\mathrm{I}_{\text {loss }}=\mathrm{I}_{\mathrm{ref}}-\mathrm{I}_{\mathrm{st}}
$$

198 in the reference site, and it could be expressed by the equation (3) (Walling et al., 2002).

$$
\mathrm{C}=\mathrm{f}(\mathrm{z})=\alpha e^{-\lambda z}
$$

200 Where, the coefficients of $\alpha$ and $\lambda$ could be obtained through exponential fitting of the 201 depth profile of ${ }^{239,}{ }^{240} \mathrm{Pu}$ at the reference site (Fig. 5). Here, $\lambda$ is the coefficient 202 distributing profile shape of ${ }^{239,240} \mathrm{Pu}$ inventory in the soil core, the smaller the value of 203 the shape factor, the deeper the penetration of plutonium into the soil core; $\alpha$ is the 204 activity concentration of ${ }^{239,240} \mathrm{Pu}$ at $\mathrm{z}=0$ (i.e. top surface of the soil core). 


$$
\mathrm{L}=-\frac{\ln \left(1-\frac{I_{\text {loss }}}{I_{\text {ref }}}\right)}{\lambda} \times 100
$$
using equation (5) (Zhang et al., 1999).

$$
\mathrm{E}=\frac{10 \mathrm{BL}}{\mathrm{T}-1963}
$$

212 Where, $B$ is the soil bulk density $\left(\times 10^{-3} \mathrm{t} / \mathrm{m}^{3}\right)$, $\mathrm{L}$ is the thickness of the lost soil $\left(\times 10^{-2}\right.$ $\mathrm{m})$, and $\mathrm{T}$ is the sampling date (year).

3 Results and discussion

3.1 Distribution of ${ }^{239,240} \mathrm{Pu}$ activity concentrations and inventories in the soil

The ${ }^{239,240} \mathrm{Pu}$ activity concentrations in the surface soil $(0-4 \mathrm{~cm})$ at the top area in

219 the soil profiles D1 and Y1 range from $0.304 \pm 0.026 \mathrm{mBq} / \mathrm{g}$ to $1.20 \pm 0.07 \mathrm{mBq} / \mathrm{g}$ (Fig.

2202 and Fig. 3), which close to the reported ranges of $(0.466-1.62) \mathrm{mBq} / \mathrm{g}$ in the same

221 latitudes (Xu et al., 2015). ${ }^{239,240} \mathrm{Pu}$ activity concentration in $0-2 \mathrm{~cm}$ depth at site D1

$222(1.20 \mathrm{mBq} / \mathrm{g})$ is three times higher than that at site $\mathrm{Y} 1(0.304 \mathrm{mBq} / \mathrm{g})$. The inventories

223 of ${ }^{239,240} \mathrm{Pu}$ at the sites D1 and $\mathrm{Y} 1$ are calculated to be $111 \pm 5 \mathrm{~Bq} / \mathrm{m}^{2}$ and $72.9 \pm 3.7 \mathrm{~Bq} / \mathrm{m}^{2}$,

224 respectively, which are similar to the values reported in Beijing $\left(107 \mathrm{~Bq} / \mathrm{m}^{2}\right)$, Dalian

$225\left(84.5-90.0 \mathrm{~Bq} / \mathrm{m}^{2}\right)$ and Chengde $\left(138 \mathrm{~Bq} / \mathrm{m}^{2}\right)$ in the similar latitude in China (Dong, 
226 2010; Ni et al., 2018; Xu et al., 2015). It can be observed that the ${ }^{239,240} \mathrm{Pu}$ activity

227 concentrations in soil column at site D1 decrease exponentially with the increased depth,

228 while the ${ }^{239,240} \mathrm{Pu}$ activity concentrations in soil column at site $\mathrm{Y} 1$ show almost uniform

229 distribution in the upper $12 \mathrm{~cm}$ and followed by an exponential decrease (Fig. 2). The

230 large difference of ${ }^{239,240} \mathrm{Pu}$ activity concentration distribution and inventory between

231 sites $\mathrm{D} 1$ and $\mathrm{Y} 1$ is related to the different sampling environment and disturbance.

232 Compared to the sampling site of D1 with the flat terrain and higher vegetation

233 coverage (90\%) and without obvious disturbance as well as potential soil accumulation

234 or erosion, the soil profile of Y1 might be disturbed and suffered erosion.

235 In the slope area (D2/Y2), the highest ${ }^{239,240} \mathrm{Pu}$ activity concentrations are

$2361.01 \pm 0.08 \mathrm{mBq} / \mathrm{g}$ at the site $\mathrm{D} 2$ and $0.444 \pm 0.053 \mathrm{mBq} / \mathrm{g}$ at the site $\mathrm{Y} 2$, which are lower

237 than that at site D1 (1.20 $\pm 0.07 \mathrm{mBq} / \mathrm{g})$ (Fig. 2 and Fig. 3). The estimated inventories of

$238{ }^{239,240} \mathrm{Pu}$ at site $\mathrm{D} 2\left(53.5 \pm 2.1 \mathrm{~Bq} / \mathrm{m}^{2}\right)$ and $\mathrm{Y} 2\left(56.5 \pm 3.1 \mathrm{~Bq} / \mathrm{m}^{2}\right)$ are about half of the

239 inventory at site $\mathrm{D} 1\left(111 \mathrm{~Bq} / \mathrm{m}^{2}\right)$. This should results from the fact that the surface soil

240 is easily lost at the slope $\left(>25^{\circ}\right)$ area by rainfall runoff, especially in the case of heavy

241 rain. It was observed that the highest ${ }^{239,240} \mathrm{Pu}$ activity concentration at D2 occurs in the

242 top soil $(0-2 \mathrm{~cm})$, while at the site of $\mathrm{Y} 2$, the highest value occurs in the subsurface

243 layer in the depth of 8-10 cm, indicating a different extent of soil erosion/accumulation

244 at two sites. In the early stage of ecological rehabilitation, the vegetation (grass)

245 coverage of the land for the natural rehabilitation by native grass is higher than that for

246 artificial rehabilitation by planting trees due to the rapid growth rate of the grass. As a 
result, a higher loss of the upper soil $(0-8 \mathrm{~cm})$ at $\mathrm{Y} 2$ happened compared to only the top

248 soil $(0-2 \mathrm{~cm})$ at D2 due to the water and wind erosion. The lower value of the maximum

$249{ }^{239,240} \mathrm{Pu}$ activity concentration and low total inventory of ${ }^{239,240} \mathrm{Pu}$ at site $\mathrm{Y} 2$ indicate a

250 significant soil erosion occurred at this site, while the increased ${ }^{239},{ }^{240} \mathrm{Pu}$ activity

251 concentrations with depth in the upper $8 \mathrm{~cm}$ soil at site $\mathrm{Y} 2$ might imply that there is an

252 accumulation of the low ${ }^{239,240} \mathrm{Pu}$ soil originated from the upper part in this catchment

253 at this site.

254 In the base area $(\mathrm{D} 3 / \mathrm{Y} 3)$, the highest ${ }^{239,240} \mathrm{Pu}$ activity concentrations are $2550.905 \pm 0.084 \mathrm{mBq} / \mathrm{g}$ at D3 and $0.990 \pm 0.149 \mathrm{mBq} / \mathrm{g}$ at $\mathrm{Y} 3$ (Fig. 2 and Fig. 3), also lower 256 than that at the site $\mathrm{D} 1(1.20 \mathrm{mBq} / \mathrm{g})$. The estimated inventories of ${ }^{239,240} \mathrm{Pu}$ are $75.4 \pm 2.5$

$257 \mathrm{~Bq} / \mathrm{m}^{2}$ at site $\mathrm{D} 3$ and $186 \pm 4 \mathrm{~Bq} / \mathrm{m}^{2}$ at $\mathrm{Y} 3$. Compared to the site D1, a lower inventory 258 of ${ }^{239,240} \mathrm{Pu}\left(75.4 \mathrm{~Bq} / \mathrm{m}^{2}\right)$ at $\mathrm{D} 3$ indicates that the soil erosion occurred also at this site 259 (D3). Although this site is located in the base area of this catchment, but not flat instead 260 with a slope of $>20^{\circ}$, causing a loss of the surface soil by wind and runoff of the 261 precipitation. The inventory of ${ }^{239,240} \mathrm{Pu}\left(186 \mathrm{~Bq} / \mathrm{m}^{2}\right)$ at site $\mathrm{Y} 3$ is higher than that at 262 reference site $\mathrm{D} 1\left(111 \mathrm{~Bq} / \mathrm{m}^{2}\right)$, indicating an extra input of ${ }^{239,240} \mathrm{Pu}$ associated particles 263 (soil) occurred in this base area. Based on the results that most of the plutonium $(>95 \%)$ 264 presents in the upper $22 \mathrm{~cm}$ soil layer at D1 and Y1 sites in this region, the inventories 265 of ${ }^{239,240} \mathrm{Pu}$ at the site $\mathrm{Y} 3$ are estimated to be $89.6 \mathrm{~Bq} / \mathrm{m}^{2}$ in the layer of $0-22 \mathrm{~cm}$ and $26696.7 \mathrm{~Bq} / \mathrm{m}^{2}$ in the deep soil $(>22 \mathrm{~cm})$, showing $52 \%$ of plutonium presents in the deep 267 layer $(>22 \mathrm{~cm})$. These results imply that a significant accumulation of soil occurred in 
the base area (Y3) in the YJG catchment, and the upper layer $(0-22 \mathrm{~cm})$ soil with low activity concentration of ${ }^{239,240} \mathrm{Pu}$ might originated from the erosion of soil in the slope area in the early stage of ecological rehabilitation in the YJG catchment.

\subsection{Source of plutonium isotopes in Nanxiaohegou watershed}

The measured ${ }^{240} \mathrm{Pu} /{ }^{239} \mathrm{Pu}$ atomic ratios (Fig. 4) are similar and distributed in a narrow range of $0.142-0.227$ with an average of $0.186 \pm 0.017$ in all 6 soil depth profiles. These values agree well with that of global fallout (0.178 \pm 0.023$)$ (Kelley et al., 1999), but are significantly different with those in the nuclear weapons (0.01-0.07) (Chiappini

278 (Warneke et al., 2002). These results suggest that plutonium in the soil profiles in this region mainly originated from the global fallout of the nuclear weapons tests.

281 substances to the environment, but most of them were dispersed and deposited in the 282 local region and some parts of Europe (Levi, 1991; Muramatsu et al., 2000). Although 283 very low level ${ }^{131}$ I and ${ }^{137} \mathrm{Cs}$ released from Chernobyl accident were measured in China, 284 no measured Chernobyl-derived plutonium was reported in China, since plutonium is 285 not volatile element, a small amount of plutonium released as relative bigger particles 286 during Chernobyl accident was mainly deposited in nearby areas. A small signal of 287 Chernobyl derived plutonium was measured in the aerosol samples collected during the 288 accident in Japan, but very small compared to the releases from the atmospheric nuclear 

amounts of radioactive substances into the air, but only low levels of volatile ${ }^{131} \mathrm{I}$ and

$291{ }^{137}$ Cs from the Fukushima accident were detected in China because of the dominant 292 westwards wind during the accident. It was reported that very small amount of 293 plutonium was released from the Fukushima accident, and Fukushima derived 294 plutonium was observed only in some samples in the $20 \mathrm{~km}$ area of the Fukushima 295 Daiichi NPP. No plutonium from Fukushima was observed in other regions including 296 China (Zheng et al., 2013). In addition, the ${ }^{240} \mathrm{Pu} /{ }^{239} \mathrm{Pu}$ atomic ratio in the fallout from 297 the accident in Chernobyl (0.386-0.412) (Boulyga et al., 1997; Wendt et al., 1999) and 298 Fukushima (0.323-0.330) (Zheng et al., 2013) are much higher than the measured 299 values in this work, therefore, the contribution of plutonium in the studied region from 300 these two nuclear accidents can be excluded. In addition, the studied region is far away from the sites of nuclear weapons tests, 302 the nearest test site at Lop Nor is located about $1700 \mathrm{~km}$ northwest of the sampling 303 region. Although the sampling site is located in the downwind direction, but it is too far 304 to receive close-in deposition of the nuclear weapons tests conducted in this site in 305 1964-1980. There is no nuclear facility in the sampling region, the nearest facility 306 (reprocessing plant in Jiayuguan) is located $950 \mathrm{~km}$ north of the sampling region. A 307 relative lower ${ }^{240} \mathrm{Pu} /{ }^{239} \mathrm{Pu}$ ratio of 0.158 (in average) was reported in soil samples 308 collected in Jiuquan region 300-500 km east of Lop Nor, which was attributed to more 309 than $40 \%$ contribution from the Chinese Nuclear weapons tests in Lop Nor. (Bu et al. 
310 2015). While, the investigations in the north China do not show obvious close-in

311 deposition of plutonium in large area of 500-2000 km distance to this nuclear weapons

312 test site and reprocessing facility in Jiayuguan, and $\operatorname{similar}{ }^{240} \mathrm{Pu} /{ }^{239} \mathrm{Pu}$ ratios as global

313 fallout were reported in the soil from Lanzhou (0.188 \pm 0.009$)$ (Zheng et al., 2009),

314 Zhongxiang $(0.186 \pm 0.008)$ and Xiangyang $(0.198 \pm 0.006)$ (Dong, 2010), as well as

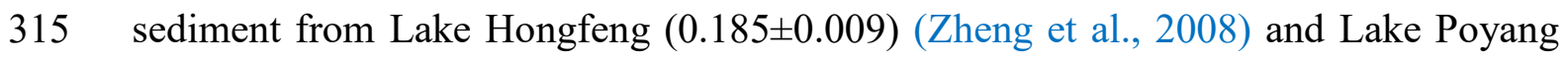

$316(0.187 \pm 0.004)$ (Liao et al., 2008) in China. This supports that the dominant source of

317 plutonium isotopes in the study region is the global fallout of nuclear weapons tests

318 before 1980. Therefore, plutonium in this region is suitable for soil erosion 319 investigation.

\section{$321 \quad 3.3$ Selection of reference site}

322 Two soil cores (D1 and Y1) were collected on the top of the two catchments. The

323 sampling site D1 on the top of the DZG catchment is located in a flat area without

324 visible disturbance, and is well covered by grass. The distribution of ${ }^{239,240} \mathrm{Pu}$ in this

325 soil core (Fig. 2 and Fig. 3) shows an exponentially declining trend with increased depth,

326 and the highest activity concentration was observed in the top layer. This suggests that

327 there is no disturbances in this area, at least since 1963 when the major global fallout

328 occurred. The most plutonium ( $>95 \%$ ) in the soil core was found in the top $10 \mathrm{~cm}$,

329 indicating a very slow migration of plutonium since its deposition on the land. This

330 might be attributed to the strong association/binding of plutonium with the soil particles 
331 (Zhang et al., 2010). Soil in Nanxiaohegou watershed contain high silt (67-74\%), but 332 not high organic matter content (0.7-1.4\%). The soil particles in watershed are quick 333 small $(<0.5 \mathrm{~mm})$ (Guo et al. 2018). It has been reported that the fallout plutonium is 334 mainly associated with fine particles and organic substances in soil, and the mobile 335 species of plutonium (water soluble or exchangeable fractions) in soil account for a 336 very small fraction (Qiao et al., 2012).

337 The total inventory of ${ }^{239,240} \mathrm{Pu}$ in the soil core at site $\mathrm{D} 1$ is calculated to be 111 $338 \mathrm{~Bq} / \mathrm{m}^{2}$ by summing up ${ }^{239} \mathrm{Pu}+{ }^{240} \mathrm{Pu}$ in all intervals of the entire soil profile. This value 339 agrees well with the reported global fallout of plutonium $\left({ }^{239,240} \mathrm{Pu}\right)$ in the similar 340 latitude, e.g. Lake Erie $\left(\sim 42^{\circ} \mathrm{N}\right)$ in America $\left(108 \mathrm{~Bq} / \mathrm{m}^{2}\right)$ (Ketterer et al., 2002), 341 Euiwang $\left(\sim 37^{\circ} \mathrm{N}\right)$ in South Korea $\left(102 \mathrm{~Bq} / \mathrm{m}^{2}\right)$ (Lee et al., 1996$)$, and Dalian $\left(\sim 39^{\circ} \mathrm{N}\right)$ $342\left(84.5-90.0 \mathrm{~Bq} / \mathrm{m}^{2}\right)(\mathrm{Xu}$ et al., 2015). The variation of the total inventory in these site 343 might attributed to the different climate condition, e.g. precipitation rate. Considering 344 the declining trend of ${ }^{239,240} \mathrm{Pu}$ inventories with depth (Fig. 2), this feature indicates that 345 there has been no significant erosion and accumulation of soil in this area. Therefore, 346 this site can be used as the reference site for the evaluation the soil erosion in this 347 watershed.

348 Fig. 5 shows the distribution of the inventories of ${ }^{239,240} \mathrm{Pu}$ in each interval of soil 349 profile with the depth, a declining trend from $31.2 \mathrm{~Bq} / \mathrm{m}^{2}$ in the top layer to $0.1 \mathrm{~Bq} / \mathrm{m}^{2}$ 350 in the bottom layer is observed. The fitting analysis shows an exponentially declining 351 formula of $\mathrm{I}_{\mathrm{pu}}=3.58 \mathrm{e}^{-0.159 \mathrm{z}}$ with a correlation factor of 0.93 . 
353 concentrations of ${ }^{239.240} \mathrm{Pu}$ in each interval show a relative constant value in the depth 354 of $0-14 \mathrm{~cm}$, indicating that the site $\mathrm{Y} 1$ has probably suffered a significant disturbance, 355 and not suitable to be used as a reference site. Therefore, the D1 is selected as the 356 reference site for both catchments in the Nanxiaohegou watershed.

\subsection{Estimation of the rate, depth and intensity of soil erosion in the Nanxiaohegou}

The rate and depth of soil erosion are calculated according to the equations of (1)

$361-(5)$, the results (Table 1) show that the soil erosion rate ranges from 538 to $941 \mathrm{t} / \mathrm{km}^{2} / \mathrm{yr}$, 362 and the erosion depths range from 2.4 to $4.6 \mathrm{~cm}$ in all sites except Y3. These results 363 agree well with the reported soil erosion rate $\left(290-725 \mathrm{t} / \mathrm{km}^{2} / \mathrm{yr}\right)$ and erosion depth $364(1.06-2.65 \mathrm{~cm})$ in the other areas in the Nanxiaohegou watershed estimated using ${ }^{137} \mathrm{Cs}$ 365 as tracer ( $\mathrm{Wu}$ and $\mathrm{Kou}, 1997$ ). At the site $\mathrm{Y3}$, a negative value of $-719 \mathrm{t} / \mathrm{km}^{2} / \mathrm{yr}$ for

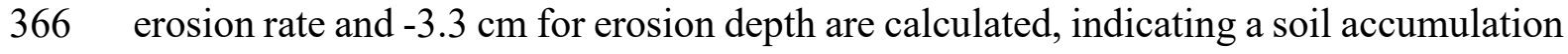

367 occurred in this area. This results from that the site Y3 is located in the base area of the

368 YJG catchment, and the eroded soil from the slope was transported and piled up in this

369 area due to its relative flat topography. It should be noted that the calculated negative

370 values for erosion rate and erosion depth could not be used to estimate the level of the

371 accumulation, because the formulas for calculation of erosion rate and depth are not 372 valid in the case of soil accumulation. 
$374 \mathrm{t} / \mathrm{km}^{2} / \mathrm{yr}$, which can be classified to be minor erosion according the criteria of 375 classification and gradation of soil erosion (SL190-2007) in China (SL190-2007, 2007).

\subsection{Evaluation of the different rehabilitation methods for reducing soil erosion}

The results in this work show a similar soil erosion rate in two catchments using

different ecological rehabilitation methods (Table 1). This might indicate that both rehabilitation methods are effective in the reduction of soil erosion.

As an experimental field for evaluation of ecological rehabilitation methods, soil

erosion rate in the Nanxiaohegou watershed was routinely monitored by measuring the

amount of soil collected after each precipitation using V-shaped runoff gathering pit,

384 which was embedded into the soil of base area. Table 2 shows the estimated values of

385 soil erosion rates in DZG and YJG catchments with the corresponding precipitation rate

386 in different periods (Chen, 2010; Li, 2006; Yuan et al., 2014). The reported erosion

387 rates by collecting the soil in the base area are only attributed to the water erosion, and

388 no wind erosion is included, because they were measured after each precipitation event.

389 With the reported data (Chen, 2010; Li, 2006; Yuan et al., 2014), the soil erosion

390 rates in the DZG and YJG catchments in different stages can be calculated and

391 compared (Table 2). In the early stage of ecological rehabilitation (1954-1962), high

392 soil erosion rate was observed in the DZG catchment $\left(4611 \mathrm{t} / \mathrm{km}^{2} / \mathrm{yr}\right)$, which is

393 classified as heavy erosion. The erosion rate in the YJG catchment (1280 t/km²/yr) was 
3943.6 times lower in this period, can classified as major erosion. A significantly decreased 395 soil erosion rate in the DZG (3000 t/ $\left.\mathrm{km}^{2} / \mathrm{yr}\right)$ in 1963-2012 was observed. An even more 396 significant reduction of soil erosion rate by a factor of about 2.8 was observed in the 397 catchment of YJG $\left(454 \mathrm{t} / \mathrm{km}^{2} / \mathrm{yr}\right)$ during the same period. This confirms that both 398 ecological rehabilitation methods are effective in the reduction of soil erosion rate, and 399 more rapid reduction of soil erosion occurred in YJG than that in DZG. The estimated 400 soil erosion rate using ${ }^{239,240} \mathrm{Pu}$ as tracer in this work in the period of 1963-2016 agrees 401 well with the previously reported values in the literatures (Chen, 2010; Li, 2006; Yuan 402 et al., 2014) using the conventional method in the YJG catchment. But much lower 403 values (538-964 t/ $\mathrm{km}^{2} / \mathrm{yr}$ ) in the DZG catchment in 1963-2016 were estimated in this 404 work compared to the reported value $\left(3000 \mathrm{t} / \mathrm{km}^{2} / \mathrm{yr}\right)$ in 1963-2012, using a 405 conventional method based on the measurement of the eroded soil in each single 406 precipitation event. The results estimated using ${ }^{239,240} \mathrm{Pu}$ in this work reflect an 407 integrated erosion, which might be more accurate for evaluation the effectiveness of the 408 ecological rehabilitation method. Based on this data, the reduction of soil erosion in the 409 DZG catchment using natural vegetation rehabilitation is also very effective, and from 410 a heavy erosion with an erosion rate of $4611 \mathrm{t} / \mathrm{km}^{2} / \mathrm{yr}$ in 1954-1962 to a minor erosion 411 with erosion rate of 538-941 t/ $\mathrm{km}^{2} / \mathrm{yr}$ in 1963-2016.

412 This result agrees well with the previous investigations in this region (Fu et al., 413 2009; Li et al., 2009). The much lower soil erosion rate in the late stage compared to 414 the early stage of the ecological rehabilitation was observed, especially for the DZG 
415 catchment where natural vegetation rehabilitation was applied since 1954. This 416 indicates that mature forest and grass are better in reducing soil erosion than young 417 forest and crops (Fu et al., 2009; Li et al., 2009).

418 The effectively suppressed soil erosion by two ecological rehabilitation methods 419 might result from that the soil erosion by rainfall splashing due to the kinetic energy of 420 rain drops was well reduced by vegetation coverage with forest and grass (Fu et al., 421 2009). Besides, the vegetation is helpful for the preservation of soil grains and water, 422 and in return helps long survival time of the vegetation. The root density also plays an 423 important role in reducing soil erosion because of the effect of enlacing and absorption 424 between root exudates and soil particles ( $\mathrm{Li}$ et al., 2014). As a consequence, the soil 425 erosion rate was significantly reduced from the first stage to the late stage of ecological 426 rehabilitation.

427 Compared to the reduction of erosion rate in the DZG and YJG catchments in the 428 same period (Table 2), it can be seen that artificial rehabilitation by planting trees/forest 429 in the YJG catchment is superior to natural vegetation rehabilitation with the grass in 430 the DZG catchment in short-time scale. This also agrees with the previous report (Fu et 431 al., 2009; Jin et al., 2018; Li et al., 2009). Investigations using ${ }^{137} \mathrm{Cs}$ tracer in other 432 Loess Plateau and Sichuan basin in China have shown that the soil erosion rate in the 433 mature forest is lower than that in the grassland (Fu et al., 2009; Li et al., 2009). A soil 434 erosion rate measurement using the runoff plots method in Ansai, China in 2003 in 435 single precipitation event showed that the average erosion rate in each precipitation 
event in the grass rehabilitated land $\left(4.6 \mathrm{t} / \mathrm{km}^{2}\right)$ is two times higher than that in the artificial forest rehabilitated land (1.0-2.6 t/ $\mathrm{km}^{2}$ ) (Zhao et al., 2006). This was attributed to the kinetic energy of rainfall (drops), which can be highly reduced by the resistance of the forest when it drops to the soil surface (Fu et al., 2009). In addition, the forest can also reduce the intensity of the wind, therefore reducing the soil erosion by wind. Comparing the reduction of the soil erosion rates in the DZG and YJG catchments between the periods of 1954-1962 and 1963-2012, it can be found that the reduction of the erosion rates in the DZG catchment $\left(1608 \mathrm{t} / \mathrm{km}^{2} / \mathrm{yr}\right)$ is two times higher than that in the YJG catchment (825 t/km²/yr) (Chen, 2010; Li, 2006; Yuan et al., 2014). This result might suggested that the natural rehabilitation is a more suitable method of ecological rehabilitation compared to the artificial rehabilitation in a long-time scale in this watershed. This might be attributed to the high coverage of the land by the vegetation with increased root density of grass and enlacing and absorption between root exudates and soil particles (Jiang et al., 2016; Li et al., 2014). It should be noted that this conclusion was obtained based on the work in such a small watershed, which might not precisely suitable as a general conclusion. Whether planting trees or seeding grass should be depended on landform condition, generally seeding grass is better for slope area and planting tree for gullies.

The slightly higher soil erosion rate in the YJG catchment $\left(551-845 \mathrm{t} / \mathrm{km}^{2} / \mathrm{yr}\right.$, with an average of $698 \mathrm{t} / \mathrm{km}^{2} / \mathrm{yr}$ ) estimated in this work using ${ }^{239,240} \mathrm{Pu}$ compared to the reported value (454 t/ $\mathrm{km}^{2} / \mathrm{yr}$ ) in 1963-2012 estimated by runoff plot might be attributed 
to the fact that the erosion rate estimated by ${ }^{239,240} \mathrm{Pu}$ tracer in this work is an integrated

458 value including wind erosion, but the value estimated by runoff plot is only for water 459 erosion. In the early stage of ecological rehabilitation, wind erosion might be significant 460 because the ground is bare. As a result, the difference of $244 \mathrm{t} / \mathrm{km}^{2} / \mathrm{yr}$ should be mainly 461 attributed to wind erosion.

\section{Conclusions}

Based on the results and discussion above, it can be concluded: 1) the dominant

465 source of ${ }^{239,240} \mathrm{Pu}$ in the investigated region in the Nanxiaohegou watershed in the 466 Chinese Loess Plateau is global fallout; 2) more than $80 \%$ of ${ }^{239,240} \mathrm{Pu}$ is present in upper $46714 \mathrm{~cm}$ layer in the most of the soil cores, and the total inventory of ${ }^{239,240} \mathrm{Pu}\left(110 \mathrm{~Bq} / \mathrm{m}^{2}\right)$ 468 at the reference site with no significant erosion and accumulation agrees well with the 469 reported values in other areas in the same latitude; 3) the plutonium isotopes as an ideal 470 tracer was successfully applied to evaluate of soil erosion and ecological rehabilitation 471 in Loess Plateau region in Northwest China, the soil erosion rates of 538-941 t/km²/yr 472 and erosion depth of $2-5 \mathrm{~cm}$ were estimated in most of the areas, which are classified 473 as minor erosion, except a site in the base area where a significant accumulation was 474 observed; 4) both natural vegetation rehabilitation and artificial tree planting 475 rehabilitation are effective for reducing the soil erosion; the natural rehabilitation shows 476 more adaptive for long term ecological rehabilitation, especially in slope area. 
479 This work was supported by the National Natural Science Foundation of China 480 (11605206, 11875261, and 41603125), the Ministry of Science and Technology of 481 China (2015FY110800), National Research Program for Key Issues in Air Pollution 482 Control (DQGG0105-02) and Chinese Academy of Sciences (132B61KYSB20180003). 483 The authors appreciate the constructive comments from the three anonymous referees.

\section{References:}

Boulyga, S.F., Erdmann, N., Funk, H., Kievets, M.K., Lomonosova, E.M., Mansel, A., Trautmann, N., Yaroshevich, O.I., Zhu, I.V., 1997. Determination of isotopic composition of plutonium in hot particles of the Chernobyl area. Radiat. Meas. 28, 349-352. https://doi.org/10.1016/S1350-4487(97)00098-X.

Branford, D., Fowler, D., Moghaddam, M.V., 2004. Study of Aerosol Deposition at a Wind Exposed Forest Edge Using ${ }^{210} \mathrm{~Pb}$ and ${ }^{137} \mathrm{Cs}$ Soil Inventories. Water, Air and downwind from Lop Nor: regional fallout vs. global fallout. Sci. Rep. 5, 12262. https://doi.org/10.1038/srep12262.

496 Cai, Q., 2001. Soil erosion and management on the Loess Plateau. J. Geogr. Sci. 11, 53-70. https://doi.org/10.1007/BF02837376. 
498 Chen, P., 2010. A study on influences of land use pattern changing on soil and water 499 loss in small watershed of Loess Plateau gully region. Beijing Forestry University $500 \quad$ (in Chinese).

501 Chen, Y., Wang, K., Lin, Y., Shi, W., Song, Y., He, X., 2015. Balancing green and 502 grain trade. Nat. Geosci. 8, 739-741. https://doi.org/10.1038/ngeo2544.

503 Chiappini, R., Pointurier, F., J.C.Millies-Lacroix, Lepetit, G., Hemet, P., 1999. $504{ }^{240} \mathrm{Pu} /{ }^{239} \mathrm{Pu}$ isotopic ratios and ${ }^{239+240} \mathrm{Pu}$ total measurements in surface and deep 505 waters around Mururoa and Fangataufa atolls compared with Rangiroa atoll (French 506 Polynesia). Sci. Total Environ. 237-238, 269-276. https://doi.org/10.1016/S0048$507 \quad \underline{9697(99) 00141-2 .}$

508 Dong, W., 2010. Distribution and Behavior of Pu Isotopes in the Environment. Peking $509 \quad$ University. (in Chinese).

510 Fu, B., Wang, S., Liu, Y., Liu, J., Liang, W., Miao, C., 2017. Hydrogeomorphic 511 Ecosystem Responses to Natural and Anthropogenic Changes in the Loess Plateau 512 of China. Annu. Rev. Earth Planet. Sci. 45, 223-243. $513 \quad$ https://doi.org/10.1146/annurev-earth-063016-020552.

514 Fu, B., Wang, Y., Lu, Y., He, C., Chen, L., Song, C., 2009. The effects of land-use 515 combinations on soil erosion: a case study in the Loess Plateau of China. Prog. Phys. 516 Geogr. 33, 793-804. https://doi.org/10.1177/0309133309350264. 
517 Fu, S., Fu, J., Wang, X., Liu, B., Yuan, A., 2003. Sediment Content Measurement in 518 Collecting Tanks of Runoff Plots. Bull. Soil Water Conserv. (in Chinese). 23, 39519 41. https://doi.org/10.13961/j.cnki.stbctb.2003.06.011.

520 Guo, M.M., Wang, W.L., Kang, H.L., Yang, B., 2018. Changes in soil properties and 521 erodibility of gully head induced by vegetation restoration on the Loess Plateau, 522 China. J. Arid Land. 10(5), 712-725. https://doi.org/10.1007/s40333-018-0121-z

523 Hirose, K., Igarashi, Y., Aoyama, M., Miyao, T., (2001). Long-term trends of 524 plutonium fallout observed in Japan. in Radioactivity in the Environment, Vol 1. 2001, 251-266. https://doi.org/10.1016/S1569-4860(01)80018-8

526 Hoo, W.T., Fifield, L.K., Tims, S.G., Fujioka, T., Mueller, N., 2011. Using fallout https://doi.org/10.1016/j.jenvrad.2010.06.010.

529 Jiang, W., Yang, S., Yang, X., Gu, N., 2016. Negative impacts of afforestation and 530 economic forestry on the Chinese Loess Plateau and proposed solutions. Quat. Int. 399, 165-173. https://doi.org/10.1016/j.quaint.2015.04.011.

532 Jin, Z., Guo, L., Lin, H., Wang, Y., Yu, Y., Chu, G., Zhang, J., 2018. Soil moisture 533 response to rainfall on the Chinese Loess Plateau after a long-term vegetation 534 rehabilitation. Hydrol. Process. 32, 1738-1754. https://doi.org/10.1002/hyp.13143. 535 Kelley, J.M., Bond, L.A., Beasley, T.M., 1999. Global distribution of Pu isotopes and $536 \quad{ }^{237} \mathrm{~Np}$. Sci. Total Environ. 237-238, 483-500. https://doi.org/10.1016/S0048- 
538 Lal, R., Tims, S.G., Fifield, L.K., Wasson, R.J., Howe, D., 2013. Applicability of ${ }^{239} \mathrm{Pu}$

539 as a tracer for soil erosion in the wet-dry tropics of northern Australia. Nucl. Instrum.

540 Meth. Phys. Res. B. 294, 577-583. https://doi.org/10.1016/j.nimb.2012.07.041.

541 Larsson, H., 1993. Linear regressions for canopy cover estimation in Acacia

542 woodlands using Landsat-TM, -MSS and SPOT HRV XS data. Int. J. Remote

$543 \quad$ Sensing. 14, 2129-2136. https://doi.org/10.1080/01431169308954025.

544 Levi, H.W., 1991. Radioactive deposition in Europe after the Chernobyl accident and

545 its long-term consequences. Ecol. Res. 6, 201-216.

$546 \quad$ https://doi.org/10.1007/bf02347162.

547 Li, M., 2006. The influence of vegetation change on hydrologic factor in nanxiaohegou.

$548 \quad$ Xi'an University of Technology (in Chinese).

549 Li, M., Li, Z., Yao, W., Liu, P., 2009. Estimating the erosion and deposition rates in a 550 small watershed by the ${ }^{137}$ Cs tracing method. Appl. Radiat. Isot. 67, 362-366.

$551 \quad$ https://doi.org/10.1016/j.apradiso.2008.10.011.

552 Li, Q., Liu, G.-b., Xu, M., Zhang, Z., 2014. Relationship of Soil Erodibility, Soil

553 Physical Properties, and Root Biomass with the Age of caragana Korshinskii Kom.

554 Plantations on the Hilly Loess Plateau, China. Arid Land Res. Manag. 28, 311-324.

$555 \quad$ https://doi.org/10.1080/15324982.2013.855957.

556 Liao, H., Zheng, J., Wu, F., Yamada, M., Tan, M., Chen, J., 2008. Determination of 557 plutonium isotopes in freshwater lake sediments by sector-field ICP-MS after 
560 Liu, B., Liu, G., Wang, D.a., Wu, Y., Duan, X., Li, J., Shen, B., Meng, L., Gao, Y., 561 2018. A field survey method for regional gully erosion: A case study in northeastern China. Sci. Soil Water Conserv. (in Chinese). 16, 34-40. https://doi.org/10.16843/j.sswc.2018.04.005.

564 Muramatsu, Y., Rühm, W., Yoshida, S., Tagami, K., Uchida, S., Wirth, E., 2000. 565 Concentrations of ${ }^{239} \mathrm{Pu}$ and ${ }^{240} \mathrm{Pu}$ and Their Isotopic Ratios Determined by ICP566 MS in Soils Collected from the Chernobyl 30-km Zone. Environ. Sci. Technol. 34, 2913-2917. https://doi.org/10.1021/es0008968.

568 Ni, Y., Wang, Z., Guo, Q., Zheng, J., Li, S., Lin, J., Tan, Z., Huang, W., 2018. Distinctive distributions and migrations of ${ }^{239+240} \mathrm{Pu}$ and ${ }^{241} \mathrm{Am}$ in Chinese forest, grassland and desert soils. Chemosphere. 212, 1002-1009. $571 \quad$ https://doi.org/10.1016/j.chemosphere.2018.09.021.

572 Qiao, J., Hansen, V., Hou, X., Aldahan, A., Possnert, G., 2012. Speciation analysis of ${ }^{129} \mathrm{I},{ }^{137} \mathrm{Cs},{ }^{232} \mathrm{Th},{ }^{238} \mathrm{U},{ }^{239} \mathrm{Pu}$ and ${ }^{240} \mathrm{Pu}$ in environmental soil and sediment. Appl.

574 Radiat. Isot. 70, 1698-1708. https://doi.org/10.1016/j.apradiso.2012.04.006.

575 Sepuru, T.K., Dube, T., 2018. An appraisal on the progress of remote sensing 576 applications in soil erosion mapping and monitoring. Remote Sens. Appl.: Soc.

577 Environ. 9, 1-9. https://doi.org/10.1016/j.rsase.2017.10.005. 

of Water Resources of the People's Republic of China (in Chinese). China. progress of soil erosion of purple soil slope farmland and its prevention and control measures Water

Conserv.

China.

$42-47+69$. https://doi.org/10.14123/j.cnki.swcc.2018.0043.

UNSCEAR, 2000. Sources and effects of ionizing radiation. Report to the General 585 Assembly, with Scientific Annexes. Volume II: Effects. United Nations, New York. pp.156-160.

Walling, D.E., He, Q., Appleby, P.G., 2002. Conversion models for use in soil-erosion, 588 soil-redistribution and sedimentation investigations, In: Zapata, F. (Ed.) Handbook

589 for the assessment of soil erosion and sedimentation using environmental 590 radionuclides, Kluwer Ac. Publ., Dordrecht,The Netherlands. pp. 111-164.

591 Walling, D.E., He, Q., Blake, W., 1999. Use of ${ }^{7} \mathrm{Be}$ and ${ }^{137} \mathrm{Cs}$ measurements to 592 document short- and medium-term rates of water-induced soil erosion on 593 agricultural land. Water Resour. Res. 35, 3865-3874. https://doi.org/10.1029/1999WR900242.

595 Warneke, T., Croudace, I.W., Warwick, P.E., Taylor, R.N., 2002. A new ground-level 596 fallout record of uranium and plutonium isotopes for northern temperate latitudes. 597 Earth Planet. Sci. Lett. 203, 1047-1057. https://doi.org/10.1016/S0012598 $\underline{821 X(02) 00930-5}$. 
599 Wendt, K., Blaum, K., Bushaw, B.A., Grüning, C., Horn, R., Huber, G., Kratz, J.V., 600 Kunz, P., Müller, P., Nörtershäuser, W., Nunnemann, M., Passler, G., Schmitt, A., 601 Trautmann, N., Waldek, A., 1999. Recent developments in and applications of 602 resonance ionization mass spectrometry. Anal. Bioanal. Chem. 364, 471-477. $603 \quad$ https://doi.org/10.1007/s002160051370.

604 Wolf, S.F., Bates, J.K., Buck, E.C., Dietz, N.L., Fortner, J.A., Brown, N.R., 1997. 605 Physical and Chemical Characterization of Actinides in Soil from Johnston Atoll. 606 Environ. Sci. Technol. 31, 467-471. https://doi.org/10.1021/es960295+.

607 Wu, Y., Kou, Q., 1997. The method of ${ }^{137}$ Cs to study soil erosion in the loess gully 608 area of east gansu province. Bull. Soil Water Conserv. (in Chinese). 17, 7-10. $609 \quad$ https://doi.org/10.13961/j.cnki.stbctb.1997.05.002.

610 Xing, S., Zhang, W., Qiao, J., Hou, X., 2018. Determination of ultra-low level 611 plutonium isotopes $\left({ }^{239} \mathrm{Pu},{ }^{240} \mathrm{Pu}\right)$ in environmental samples with high uranium. 612 Talanta. 187, 357-364. https://doi.org/10.1016/j.talanta.2018.05.051.

613 Xu, Y., Qiao, J., Pan, S., Hou, X., Roos, P., Cao, L., 2015. Plutonium as a tracer for 614 soil erosion assessment in northeast China. Sci. Total Environ. 511, 176-185. $615 \quad$ https://doi.org/10.1016/j.scitotenv.2014.12.006.

616 Yuan, J., Zhang, F., Li, H., Gao, W., 2014. Law of soil and water loess under different 617 measures in south xiaogehou watershed. Bull. Soil Water Conserv. (in Chinese). 34, 618 39-43. https://doi.org/10.13961/j.cnki.stbctb.2014.03.009. 
619 Zhang, X.B., Walling, D.E., He, Q., 1999. Simplified mass balance models for 620 assessing soil erosion rates on cultivated land using caesium-137 measurements.

621 Hydrol. Sci. J. 44, 33-45. https://doi.org/10.1080/02626669909492201.

622 Zhang, Y., Zheng, J., Yamada, M., Wu, F., Igarashi, Y., Hirose, K., 2010.

623 Characterization of $\mathrm{Pu}$ concentration and its isotopic composition in a reference

624 fallout material. Sci. Total Environ. 408, 1139-1144. $625 \quad$ https://doi.org/10.1016/j.scitotenv.2009.11.058.

626 Zhao, G., Mu, X., Wen, Z., Wang, F., Gao, P., 2013. Soil erosion, conservation, and 627 eco-environment changes in the Loess Plateau of China. Land Degrad. Dev. 24, 628 499-510. https://doi.org/10.1002/ldr.2246.

629 Zhao, H., Liu, G., Cao, Q., Wu, R.j., 2006. Influence of different land use types on soil 630 erosion and nutrition care effect in loess hilly region. J. Soil Water Conserv. (in 631 Chinese). 20, 20-24, 54. https://doi.org/10.13870/j.cnki.stbcxb.2006.01.005.

632 Zheng, J., He, X., Walling, D., Zhang, X., Flanagan, D., Qi, Y., 2007. Assessing Soil 633 Erosion Rates on Manually-Tilled Hillslopes in the Sichuan Hilly Basin Using ${ }^{137} \mathrm{Cs}$ $634 \quad$ and $\quad{ }^{210} \mathrm{~Pb}_{\mathrm{ex}} \quad$ Measurements. Pedosphere. 17, 273-283. 635 https://doi.org/10.1016/S1002-0160(07)60034-4.

636 Zheng, J., Tagami, K., Uchida, S., 2013. Release of Plutonium Isotopes into the 637 Environment from the Fukushima Daiichi Nuclear Power Plant Accident: What Is 638 Known and What Needs to Be Known. Environ. Sci. Technol. 47, 9584-9595. 639 https://doi.org/10.1021/es402212v. 
640 Zheng, J., Wu, F., Yamada, M., Liao, H., Liu, C., Wan, G., 2008. Global fallout Pu 641 recorded in lacustrine sediments in Lake Hongfeng, SW China. Environ. Pollut. . 642 152, 314-321. https://doi.org/10.1016/j.envpol.2007.06.027.

643 Zheng, J., Yamada, M., Wu, F., Liao, H., 2009. Characterization of Pu concentration 644 and its isotopic composition in soils of Gansu in northwestern China. J. Environ. 645 Radioact. 100, 71-75. https://doi.org/10.1016/j.jenvrad.2008.10.017.

646

647

648

649

650

651

652

653

654

655

656

657

658

659

660 


\section{Caption of the figures}

663

664 Fig. 1 sampling sites in the DZG and YJG in Nanxiaohegou watershed in the loess plateau in northwest China. The elevations of the top catchments and the height from the base to the top area are $1271 \mathrm{~m}$ and $127 \mathrm{~m}$ for YJG and $1305 \mathrm{~m}$ and $160 \mathrm{~m}$ in DZG, the slopes of two catchments are $35 \square$ for YJG and $25 \square$ for DZG (slope of the sampling sites at slope); the distances among top-slope and slope-base sampling sites are $250 \mathrm{~m}$ and $100 \mathrm{~m}$ in YJG and $200 \mathrm{~m}$ and $150 \mathrm{~m}$ for DZG catchment.

671 Fig. 2 Depth distributions of ${ }^{239,240} \mathrm{Pu}$ activity concentrations in six soil profiles

672 Fig. 3. Depth distributions of ${ }^{239,240} \mathrm{Pu}$ inventories in six soil profiles

673 Fig. 4 Depth distributions of the ${ }^{240} \mathrm{Pu} /{ }^{239} \mathrm{Pu}$ atomic ratios in the sampling sites

674 Fig. 5 Depth distributions of ${ }^{239,240} \mathrm{Pu}$ inventories the soil core at sampling site D1 675 676 677 678 679 680 681 
683 Table 1. The depth and rate of soil erosion, and erosion intensity in the study site

\begin{tabular}{|c|c|c|c|c|c|c|}
\hline & D1 & D2 & D3 & Y1 & Y2 & Y3 \\
\hline $\begin{array}{l}\text { Total inventory of } \\
{ }^{239,240} \mathrm{Pu}\left(\mathrm{Bq} / \mathrm{m}^{2}\right)\end{array}$ & 111 & 53.4 & 75.4 & 72.9 & 56.5 & 186 \\
\hline Soil erosion depth $(\mathrm{cm})$ & & 4.6 & 2.4 & 2.6 & 4.2 & -3.3 \\
\hline $\begin{array}{l}\text { Soil erosion rate } \\
\qquad\left(\mathrm{t} / \mathrm{km}^{2} / \mathrm{yr}\right)\end{array}$ & & 941 & 538 & 551 & 845 & -719 \\
\hline Erosion intensity & & $\begin{array}{l}\text { minor } \\
\text { erosion }\end{array}$ & $\begin{array}{l}\text { minor } \\
\text { erosion }\end{array}$ & $\begin{array}{l}\text { minor } \\
\text { erosion }\end{array}$ & $\begin{array}{l}\text { minor } \\
\text { erosion }\end{array}$ & accumulation \\
\hline
\end{tabular}

684

685

686

687

688

689

690

691

692

693

694 
695

696 Table 2. The soil erosion rate of DZG and YJG during the different time

\begin{tabular}{lcccc}
\hline \multicolumn{1}{c}{ Time } & Soil erosion rate $\left(\mathrm{t} / \mathrm{km}^{2} / \mathrm{yr}\right)$ & Precipitation rate & \\
& DZG & YJG & $(\mathrm{mm})$ & Reference \\
\hline $1954-1962$ & 4610 & 1280 & 567 & (Chen, 2010; Li, \\
$1963-2012^{*}$ & 3000 & 454 & 414 & 2006; Yuan et al., \\
& & & & 2014) \\
$1963-2016$ & $538-941$ & $551-845$ & 556 & This study \\
\hline
\end{tabular}

697 Note: *the data are not available in 1970-1971, 1978-1986 and 1995-2011

698

699

700 


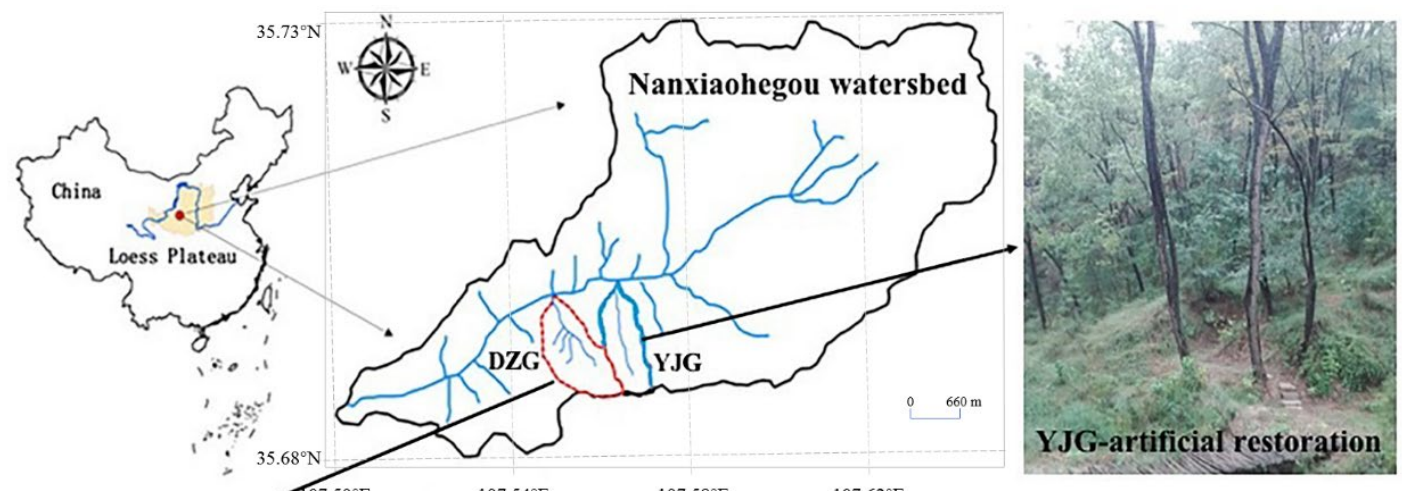

704 Fig. 1 Sampling sites in the DZG and YJG in Nanxiaohegou watershed in the Loess Plateau in northwest China. The elevations of the top catchments and the height from the base to the top area are $1271 \mathrm{~m}$ and $127 \mathrm{~m}$ for YJG and $1305 \mathrm{~m}$ and $160 \mathrm{~m}$ in DZG, the slopes of two catchments are $35^{\circ}$ for $\mathrm{YJG}$ and $25^{\circ}$ for DZG (slope of the sampling sites at slope); the distances among top-slope and slope-base sampling sites are $250 \mathrm{~m}$ and $100 \mathrm{~m}$ in YJG and $200 \mathrm{~m}$ and $150 \mathrm{~m}$ for DZG catchment. 
714

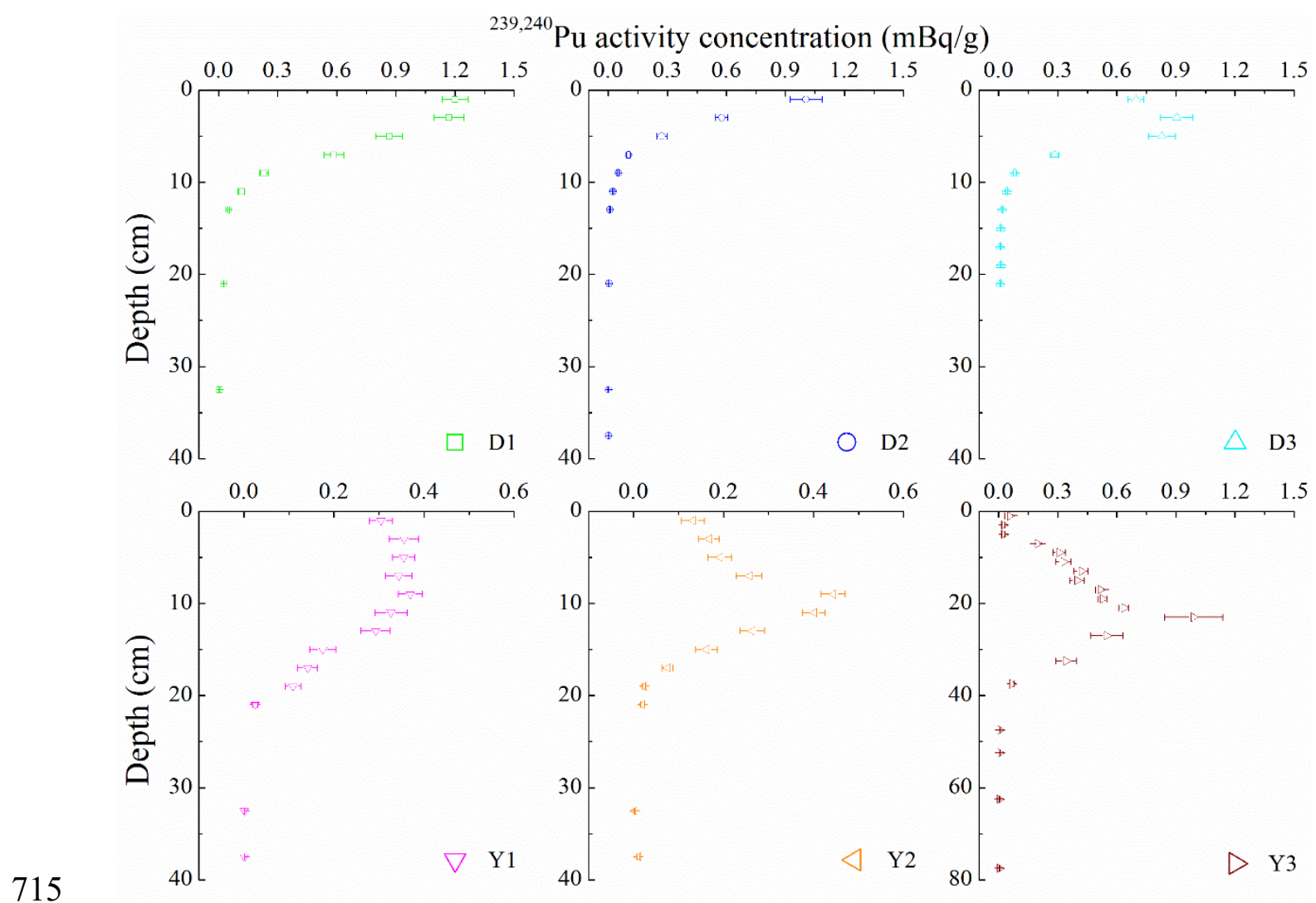

716

717

718

Fig. 2 Depth distributions of ${ }^{239,240} \mathrm{Pu}$ activity concentrations in six soil profiles 


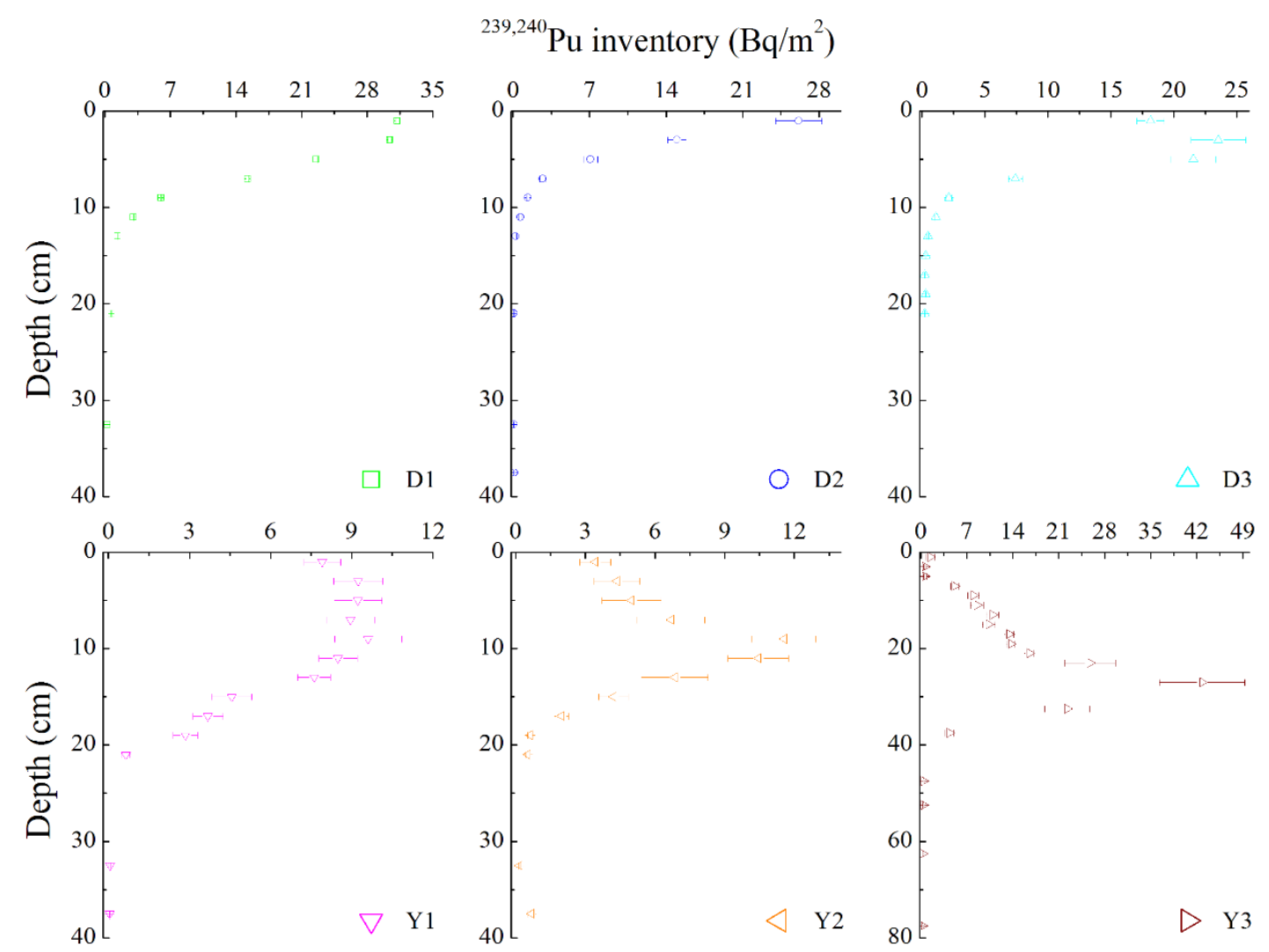

719

720

721

722 Fig. 3 Depth distributions of ${ }^{239,240} \mathrm{Pu}$ inventory in six soil profiles

723

724 


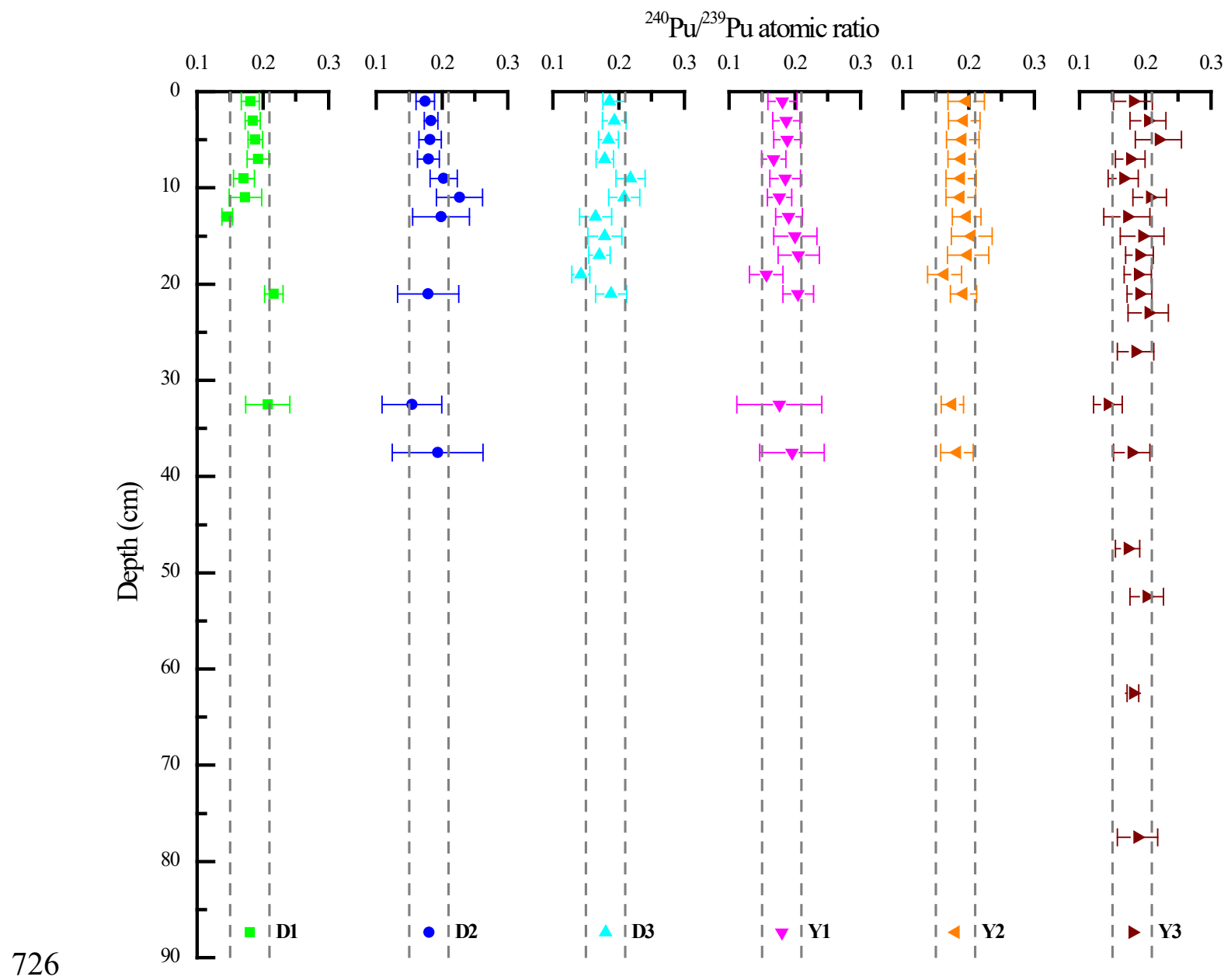

729 Fig. 4 Depth distributions of the ${ }^{240} \mathrm{Pu} /{ }^{239} \mathrm{Pu}$ atomic ratios in the sampling sites 


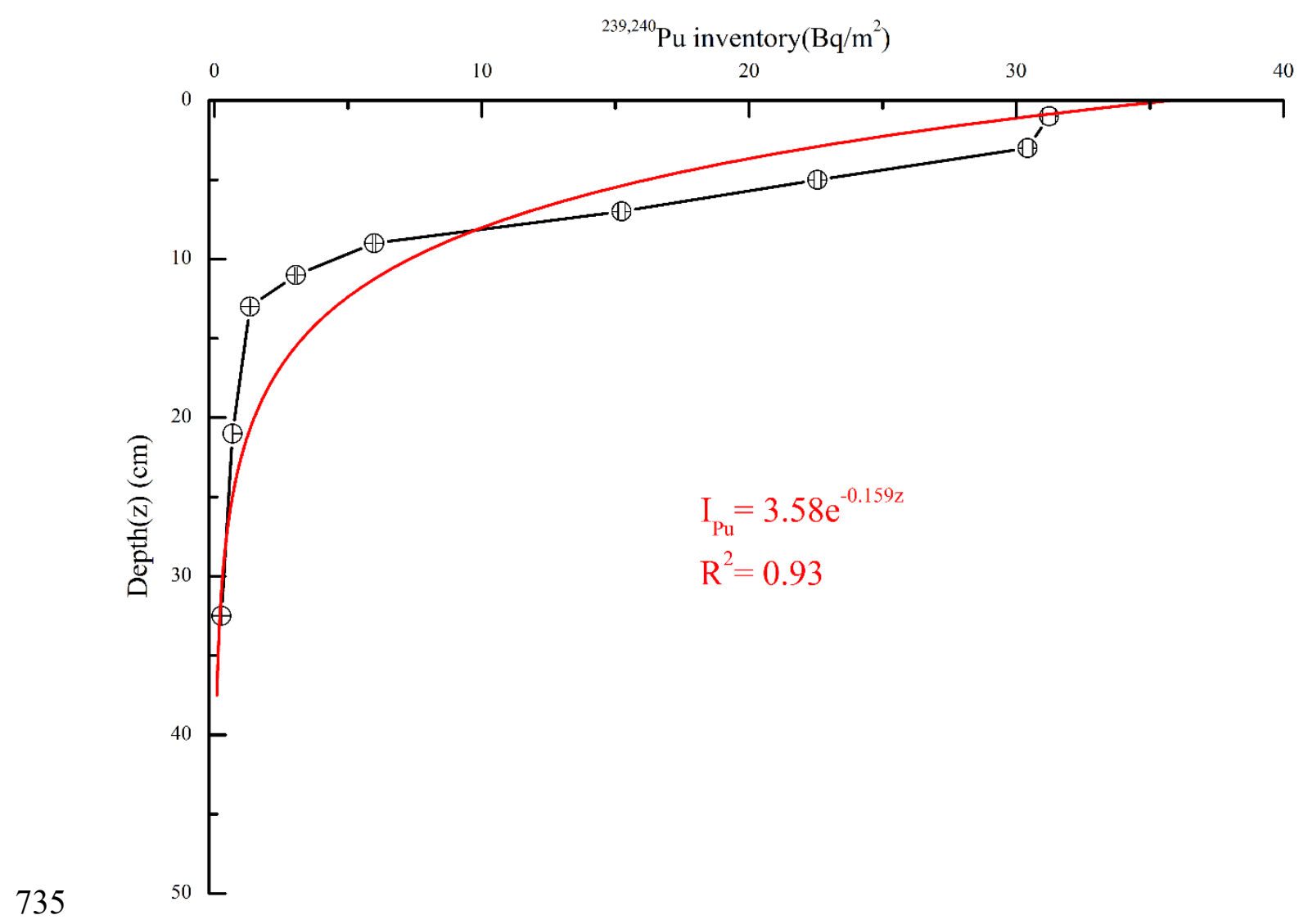

736

737 Fig. 5 Depth distribution of ${ }^{239,}{ }^{240} \mathrm{Pu}$ inventories the soil core at sampling site D1 738 